\title{
Pyriculins A and B, two monosubstituted hex-4-ene-2,3-diols and other phytotoxic metabolites produced by Pyricularia grisea isolated from buffelgrass (Cenchrus ciliaris)
}

\author{
Marco Masi, ${ }^{[a, b]}$ Susan Meyer, ${ }^{[c]}$ Marcin Górecki, ${ }^{[d]}$ Alessandro Mandoli, ${ }^{[d]}$ Lorenzo Di Bari, ${ }^{[d]}$ \\ Gennaro Pescitelli, ${ }^{*[\mathrm{~d}]}$ Alessio Cimmino, ${ }^{[\mathrm{a}]}$ Massimo Cristofaro, ${ }^{[\mathrm{b}, \mathrm{e}]}$ Suzette Clement, ${ }^{[\mathrm{c}]}$ and \\ Antonio Evidente*[a]
}

\begin{abstract}
Pyricularia grisea has been identified as a foliar pathogen on buffelgrass (Cenchrus ciliaris) in North America and was studied as a potential source of phytotoxins for buffelgrass control. Two monosubstituted hex-4-ene-2,3-diols, named pyriculins $A$ and $B$, were isolated from its culture filtrate organic extract together with (10S,11S)-(-)-epipyriculol, trans-3,4dihydro-3,4,8-trihydroxy-1(2H)-napthalenone and $(4 S)-(+)$-isosclerone. Pyriculins $A$ and $B$ were characterized by spectroscopic (essentially NMR, HRESIMS) and chemical methods as (4E)-1-(4-hydroxy-1,3-dihydroisobenzofuran-1yl)hex-4-ene-2,3-diols. The relative and absolute configuration of these compounds was determined by a combination of spectroscopic (NMR, CD) and computational tools. When bioassayed in a buffelgrass coleoptile and radicle elongation test,

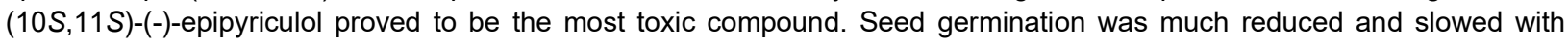
respect to the control and radicles failed to elongate. All five compounds delayed germination, but only $(10 S, 11 S)-(-)-$ epipyriculol was able to prevent radicle development of buffelgrass seedlings. It had no effect on coleoptile elongation, while the other four compounds caused significantly increased coleoptile development relative to the control.
\end{abstract}

Keywords: Buffelgrass; Pyricularia grisea; phytotoxins; pyriculins A and B; relative and absolute configuration; (10S,11S)-(-)epipyriculol

\section{Introduction}

Cenchrus ciliaris L. (syn. Pennisetum ciliare L.), also known as buffelgrass or African foxtail grass, was introduced in northwestern Mexico and southwestern United States during the 1950 's as a forage plant for cattle. ${ }^{1}$ Its fast growth, resistance to heavy grazing, drought tolerance and forage value promoted its exponential growth as an important pasture grass in many semiarid regions of the world including Texas. ${ }^{2,3}$ Unfortunately, buffelgrass started to spread into undisturbed natural areas and since the 1980's it has become one of the most serious invaders in some parts of its introduced range. ${ }^{4-6}$ Particularly dramatic is the situation in the Sonoran Desert of southern Arizona, ${ }^{7-11}$ where it has infested thousands of acres of public and private lands, including Saguaro National Park and the Coronado and Tonto National Forests. Buffelgrass invasion has negatively influenced native vegetation through competition for water, nutrients and space, and it has also caused an increased in fire frequency. ${ }^{12}$ At present, the only weapons available to deal with buffelgrass invasion into natural ecosystems are broad-spectrum herbicides (e.g., glyphosate) and physical removal with hand tools. ${ }^{13}$ The use of synthetic pesticides may select for resistance in target plants, and their residues in agricultural products can have long term risks for human and animal health. Phytotoxins produced by weed pathogenic fungi present an efficient alternative for the design of natural and potentially safe herbicides to be used in innovative biocontrol strategies. ${ }^{14}$ For example, different phytotoxic metabolites were isolated from Pyrenophora semeniperda, a potential biocontrol agent for the weed Bromus tectorum, and their potential herbicidal activity was evaluated. ${ }^{15-19}$ Three foliar pathogens (Cochliobolus australiensis, Nigrospora sphaerica and Pyricularia grisea) that are potential sources of candidate phytotoxins for buffelgrass control have been identified on buffelgrass in its North American range.

Recently, from the culture filtrate of one of these pathogens, Cochliobolus australiensis, a new phytotoxin, named cochliotoxin, was isolated together with the known compounds radicinin, radicinol and their 3 -epimers. Cochliotoxin showed strong phytotoxicity when bioassayed in a buffelgrass coleoptile elongation test and by leaf puncture bioassay against the host weed. ${ }^{20}$ A second buffelgrass foliar pathogen is Pyricularia grisea (teleomorph Magnaporthe grisea), which is now considered to be distinct from the rice blast pathogen $M$. oryzae. It is known from a broad spectrum of warm season grass hosts. It is the only foliar pathogen that has been recorded to reach epidemic levels that severely damage buffelgrass in the field. ${ }^{21,22}$ An epidemic blight disease caused by this organism in Texas during a series of unusual weather years prompted a search for a blight-resistant buffelgrass strain. ${ }^{23}$ This generalist pathogen exists in nature as a series of host-specific taxa and is known to include strains that produce host-specific phytotoxins, notably on crabgrass (Digitaria sanguinalis). ${ }^{24}$

[a] Dr. M., Masi, Dr., A., Cimmino, Prof., A., Evidente Dipartimento di Scienze Chimiche,

Università di Napoli Federico II,

Complesso Universitario Monte S. Angelo, Via Cintia 4, 80126 Napoli, Italy

Fax: +39081674330

E-mail: evidente@unina.it

[b] Dr., M., Masi, Dr., M., Cristofaro

BBCA Onlus,

Via A. Signorelli 105, 00123 Rome, Italy

[c] Dr., M., Susan, Dr., S., Clement

Shrub Sciences Laboratory, U.S. Forest Service Rocky Mountain Research Station, 735 North 500 East, Provo, Utah 84606, USA

[d] Dr., M., Górecki, Dr., A., Mandoli, Prof., L., Di Bari, Prof., G., Pescitelli Dipartimento di Chimica e Chimica Industriale, Università di Pisa, Via Moruzzi 13, 56124 Pisa, Italy

E-mail: gennaro.pescitelli@unipi.it

[e] Dr., M., Cristofaro

ENEA C.R. Casaccia, SSPT-BIOAG-PROBIO,

Via Anguillarese 301, 00123 Rome, Italy

Received: ((will be filled in by the editorial staff))

Revised: ((will be filled in by the editorial staff)) Published online: ((will be filled in by the editorial staff)) 
TABLE $1{ }^{1} \mathrm{H}$ NMR data of 1 and 2 recorded in acetone- $\mathrm{d}_{6}$ at $600 \mathrm{MHz}$

\begin{tabular}{|c|c|c|c|c|}
\hline & \multicolumn{2}{|c|}{$1 \delta_{\mathrm{H}}(\mathrm{J}$ in $\mathrm{Hz})$} & \multicolumn{2}{|c|}{$2 \delta_{\mathrm{H}}(J$ in $\mathrm{Hz})$} \\
\hline position & & $\begin{array}{l}\text { Iwasaki et al. (acetone } \\
d_{6} \text { ) }\end{array}$ & & Iwasaki et al. (acetone $d_{6}$ ) \\
\hline 1 & $\begin{array}{l}5.03 \mathrm{dd}(J=12.2, \quad J=2.1) \\
4.93 \mathrm{~d}(J=12.2)\end{array}$ & $5.02(2 \mathrm{H}$, br. s) & $\begin{array}{l}5.08 \mathrm{dd}(J=12.0) \\
4.97 \mathrm{~d}(J=12.0)\end{array}$ & $\begin{array}{l}5.10(1 \mathrm{H}, \mathrm{d}, J=12.5) \\
4.97(1 \mathrm{H}, \mathrm{d}, J=12.5)\end{array}$ \\
\hline 4 & $6.67 \mathrm{~d}(J=7.7)$ & $6.68(1 \mathrm{H}, \mathrm{d}, J=8.0)^{\mathrm{d}}$ & $6.75 \mathrm{~d}(J=7.5)$ & $6.67(1 \mathrm{H}, \mathrm{d}, \mathrm{J}=8.0)$ \\
\hline 5 & $7.11 \mathrm{t}(J=7.7)$ & $7.12(1 \mathrm{H}, \mathrm{t}, \mathrm{J}=8.0)$ & $7.12 \mathrm{t}(\mathrm{J}=7.5)$ & $7.10(1 \mathrm{H}, \mathrm{t}, \mathrm{J}=8.0)$ \\
\hline 6 & $6.67 \mathrm{~d}(\mathrm{~J}=7.7)$ & $6.68(1 \mathrm{H}, \mathrm{d}, J=8.0)^{\mathrm{d}}$ & $6.75 \mathrm{~d}(\mathrm{~J}=7.5)$ & $6.90(1 \mathrm{H}, \mathrm{d}, J=8.0)$ \\
\hline 8 & $5.40 \mathrm{ddd}(J=9.7, \quad J=2.5, \quad J=2.1)$ & $5.42(1 \mathrm{H}, \mathrm{t}, \mathrm{J}=6.0)$ & $5.38 \mathrm{dd}(J=8.4, J=4.6)$ & $5.20-5.50(1 \mathrm{H}$, diffused $\mathrm{q})$ \\
\hline 9 & $\begin{array}{l}1.84 \text { ddd }(J=14.5, \quad J=9.8, \quad J=2.5) \\
1.76 \text { ddd }(J=14.5, \quad J=9.7, \quad J=2.2)\end{array}$ & $1.80(2 \mathrm{H}, \mathrm{q}, J=6.0,4.0)$ & $\begin{array}{l}2.03 \text { ddd }(J=14.6, \quad J=4.6, J=3.6) \\
1.77 \text { ddd }(J=14.6, \quad J=9.0, J=8.4)\end{array}$ & $\begin{array}{l}1.97(1 \mathrm{H}, \mathrm{s}, \mathrm{J}=13.0,4.0,4.0) \\
1.77(1 \mathrm{H})\end{array}$ \\
\hline 10 & 3.83 ddd $(J=9.8, J=3.8, J=2.2)$ & $3.7-4.1(1 \mathrm{H}, \mathrm{m})$ & 3.84 ddd $(J=9.0, \quad J=3.7, J=3.6)$ & $3.7(1 \mathrm{H}, \mathrm{m})$ \\
\hline 11 & $3.97 \mathrm{dd}(\mathrm{J}=6.4, \quad J=3.8)$ & $3.7-4.1(1 \mathrm{H}, \mathrm{m})$ & $3.97 \mathrm{dd}(\mathrm{J}=6.1, \mathrm{~J}=3.7)$ & $3.7(1 \mathrm{H}, \mathrm{m})$ \\
\hline 12 & $5.57 \mathrm{br} \mathrm{dd^{c }}(\mathrm{J}=15.4, \mathrm{~J}=6.4)$ & $5.52(1 \mathrm{H}, \mathrm{q}, J=15.0,6.0)$ & $5.60 \mathrm{br} \operatorname{dd}^{\mathrm{c}}(J=15.4, \quad J=6.1)$ & $5.55(1 \mathrm{H}, \mathrm{q}, \mathrm{J}=15.0,5.0)$ \\
\hline 13 & $5.68 \mathrm{dq}(\mathrm{J}=15.4, \quad J=6.3)$ & $5.75(1 \mathrm{H}, \mathrm{o}, J=15.0,6.0)$ & $5.71 \mathrm{dq}(\mathrm{J}=15.4, \quad J=6.3)$ & $5.77(1 \mathrm{H}, \mathrm{o}, J=15.0,5.0)$ \\
\hline 14 & $1.66 \mathrm{br} \mathrm{d}^{\mathrm{c}}(\mathrm{J}=6.3)$ & $1.73(3 \mathrm{H}, \mathrm{d}, \mathrm{J}=6.0)$ & $1.67 \operatorname{br~d}^{c}(J=6.3)$ & $1.70(3 \mathrm{H}, \mathrm{d}, \mathrm{J}=5.0)$ \\
\hline
\end{tabular}

It therefore seems logical to investigate whether strains from buffelgrass also produce phytotoxins with some degree of selective action.

This manuscript reports on the isolation and chemical and biological characterization of two monosubstituted hex-4-ene2,3-diols, named pyriculins $A$ and $B$ (1 and 2; Fig. 1) together with (10S,11S)-(-)-epipyriculol, ${ }^{25-27}$ trans-3,4-dihydro-3,4,8trihydroxy-1(2H)-napthalenone ${ }^{28,29}$ and $(4 S)-(+)$-isosclerone ${ }^{30-32}$ $(3,4$ and $\mathbf{5}$, respectively; Fig. 1$)$.

\section{Materials and Methods}

\section{GENERAL EXPERIMENTAL PROCEDURES}

Optical rotations were measured in solution on a Jasco P-1010 digital polarimeter (Japan, Tokyo); IR spectra were recorded as glassy film on a Perkin-Elmer (Waltham, Massachusetts, USA) Spectrum One FT-IR spectrometer; UV spectra were recorded in $\mathrm{MeOH}$ or acetonitrile solutions on a Perkin-Elmer Lambda 25 UV/Vis spectrophotometer and a Jasco V-650 spectrophotomer; ECD spectra were recorded on a Jasco J-715 spectropolarimeter, in acetonitrile solutions and quartz cells with 0.01-0.05 cm path-length. ${ }^{1} \mathrm{H}$ and ${ }^{13} \mathrm{C}$ NMR spectra were recorded at 600,500 and 400 , and at 150,125 and $100 \mathrm{MHz}$, respectively, in $\mathrm{CDCl}_{3}, \mathrm{CD}_{3} \mathrm{OD}$ or acetone- $d_{6}$ on Varian (Palo Alto, California, USA) and Bruker (Karlsruhe, Germany) spectrometers. The same solvent was used as an internal standard. Carbon multiplicities were determined by DEPT spectra. $^{33}$ DEPT, COSY-45, HSQC, HMBC and NOESY experiments $^{33}$ were performed using Bruker or Varian microprograms. HRESIMS and ESI spectra were recorded on Shimadzu (Kyoto, Japan) LCMS-IT-TOF Mass Spectrometer and Agilent (Milan, Italy) 6230 Accurate-Mass TOF LC/MS instruments. Analytical and preparative TLC were performed on silica gel (Kieselgel 60, $F_{254}, 0.25$ and $0.5 \mathrm{~mm}$ respectively; Merck, Darmstadt, Germany) or on reverse phase (KC18 $F_{254}$, $0.20 \mathrm{~mm}$; Whatman, Maidstone, UK) plates; the spots were visualized by exposure to UV light and/or iodine vapors and/or by spraying first with $10 \% \mathrm{H}_{2} \mathrm{SO}_{4}$ in $\mathrm{MeOH}$, and then with $5 \%$ phosphomolybdic acid in EtOH followed by heating at $110{ }^{\circ} \mathrm{C}$ for $10 \mathrm{~min}$. CC: silica gel (Merck, Kieselgel 60, 0.063-0.200 mm).

\section{FUNGAL STRAIN}

The $P$. grisesa strain used in this study (SNM22) was isolated from diseased buffelgrass tissue collected in Saguaro National Monument, Arizona, USA in autumn 2014.

\section{EXTRACTION AND PURIFICATION}

The strain of $P$. grisea was grown on PDB (potato dextrose broth) culture at laboratory temperature by inoculating $3 \mathrm{~L}$ of sterile broth in $1 \mathrm{~L}$ Erlenmeyer flasks with fragments of mycelial mat produced on PDA (potato dextrose agar) and incubating in shaker culture for 14 days. Mycelium was then removed from the medium by centrifugation and filtering, and the resulting filtrates were lyophilized and frozen at $-20{ }^{\circ} \mathrm{C}$. The lyophilized culture filtrate $(3 \mathrm{~L})$ was dissolved in distilled $\mathrm{H}_{2} \mathrm{O}(1 / 10$ of its original volume, $\mathrm{pH} 8)$, and then extracted with EtOAc $(3 \times 300 \mathrm{ml})$. The organic extracts were combined, dehydrated with anhydrous $\mathrm{Na}_{2} \mathrm{SO}_{4}$ and evaporated under reduced pressure, yielding a brown oil $(212.8 \mathrm{mg})$. This oil was purified by CC eluted with $\mathrm{CHCl}_{3} / i-\mathrm{PrOH}(9: 1, \mathrm{v} / \mathrm{v})$, yielding eleven groups of homogeneous fractions. The residue of the third fraction $(11.7 \mathrm{mg})$ was further purified by TLC on silica gel eluted with $\mathrm{CHCl}_{3} / i-\mathrm{PrOH}(9: 1, \mathrm{v} / \mathrm{v})$ yielding epi-pyriculol $\left(3,7.79 \mathrm{mg}, R_{f} 0.57\right.$, Fig.1) and isosclerone $\left(5,1.19 \mathrm{mg}, R_{f} 0.66\right.$, Figure 1$)$ as amorphous solids. The residue of the fourth $(10.4 \mathrm{mg})$ and fifth $(24.1 \mathrm{mg})$ fractions were combined and further purified by TLC on reverse phase, eluent $\mathrm{MeOH} / \mathrm{H}_{2} \mathrm{O}(6: 4, \mathrm{v} / \mathrm{v})$, yielding pyriculin B $\left(2,8.2 \mathrm{mg}, R_{f} 0.40\right.$ Figure 1) as an oily homogeneous compound. The residue of the seventh fraction $(29.7 \mathrm{mg}$ ) was further purified by TLC eluted two times with petroleum ether/Me ${ }_{2} \mathrm{CO}(6.5: 3.5, \mathrm{v} / \mathrm{v})$ obtaining a white amorphous solid named pyriculin $\mathrm{A}\left(1,7.76 \mathrm{mg}, R_{f} 0.44\right.$, Figure 1), and trans-3,4-dihydro-3,4,8-trihydroxy-1 $(2 H)$ napthalenone $\left(4,2.5 \mathrm{mg}, R_{f} 0.56\right.$, Fig. 1$)$ as an amorphous solid.

\section{Pyriculin A (1)}

$[\alpha]^{25} \mathrm{D}-8.6$ (c 0.07 in $\left.\mathrm{EtOH}\right) ;{ }^{1} \mathrm{H}$ and ${ }^{13} \mathrm{C}$ NMR see Table 1 and 2; IR: $v_{\max }=3338,1599,1468,1375,1282 \mathrm{~cm}^{-1}$; UV-vis $(\mathrm{MeOH})$ : $\lambda_{\max }(\log \varepsilon)=270$ (3.40), 278 (3.36) nm; HRMS (ESI, m/z): [M + $\mathrm{Na}]^{+}$calcd for $\mathrm{C}_{14} \mathrm{H}_{18} \mathrm{NaO}_{4}, 273.1103$; found, 273.1111.

\section{Pyriculin B (2)}

$[\alpha]^{25} \mathrm{D}+3.8$ (c 0.03 in EtOH); ${ }^{1} \mathrm{H}$ and ${ }^{13} \mathrm{C}$ NMR see Table 1 and 2; IR: $v_{\max }=3339,1599,1469,1375,1294 \mathrm{~cm}^{-1}$; UV-vis $(\mathrm{MeOH})$ : $\lambda_{\max }(\log \varepsilon) 270$ (3.41), 278 (3.38) nm; HRMS (ESI, m/z): [M + $\mathrm{Na}]^{+}$calcd for $\mathrm{C}_{14} \mathrm{H}_{18} \mathrm{NaO}_{4}, 273.1103$; found, 273.1106.

\section{(10S,11S)-(-)-Epipyriculol (3)}

$[\alpha]^{25} \mathrm{D}-31.2$ (c 0.07 in $\mathrm{CHCl}_{3}$ ) [lit. ${ }^{26}:[\alpha]^{25} \mathrm{D}-31$ (c 0.41 in $\left.\mathrm{CHCl}_{3}\right)$ ]; ${ }^{1} \mathrm{H}$ NMR spectrum was very similar to that previously described; ${ }^{25-27} \operatorname{ESIMS}(\mathrm{m} / \mathrm{z}): 287[\mathrm{M}+\mathrm{K}]^{+}, 271[\mathrm{M}+\mathrm{Na}]^{+}$.

trans-3,4,8-Trihydroxy-3,4-dihydronaphthalen-1(2H)-one (4) $[\alpha]^{25} \mathrm{D}-41.8$ (c 0.02 in $\mathrm{MeOH}$ ) [lit. ${ }^{28}:[\alpha]^{25} \mathrm{D}-36.0$ in $\mathrm{MeOH}$ ]; ${ }^{1} \mathrm{H}$ NMR spectrum was very similar to that previously described;28-29 $\operatorname{ESIMS}(\mathrm{m} / \mathrm{z}): 217[\mathrm{M}+\mathrm{Na}]^{+}, 195[\mathrm{M}+\mathrm{H}]^{+}$.

(4S)-(+)-isosclerone (5)

$[\alpha]^{25}+16.8$ (c 0.01 in $\mathrm{CHCl}_{3}$ ) $\left[\right.$ lit. ${ }^{32}:[\alpha]^{25}{ }_{\mathrm{D}}+24.5$ (c 0.14 in $\left.\mathrm{CHCl}_{3}\right)$ ]; ${ }^{1} \mathrm{H}$ NMR spectrum was very similar to that previously 
described; ${ }^{30} \operatorname{ESIMS}(\mathrm{m} / \mathrm{z}): 217[\mathrm{M}+\mathrm{K}]^{+}, 201[\mathrm{M}+\mathrm{Na}]^{+}, 179[\mathrm{M}+$ $\mathrm{H}]^{+}$.

\section{2-Phenyl-1,3,2-dioxaborolane of pyriculin A (1a)}

A solution of 1 (approx. $1.5 \mathrm{mg}, 6 \mu \mathrm{mol})$ in acetone- $\mathrm{d}_{6}(0.5 \mathrm{~mL})$ was treated with phenylboronic acid $0.5 \mathrm{M}$ in acetone- $\mathrm{d}_{6}(25 \mu \mathrm{L}$, $12 \mu \mathrm{mol})$. The progress of the derivatization reaction was monitored by ${ }^{1} \mathrm{H}$ NMR, which showed essentially complete consumption of 1 within $90 \mathrm{~min}$ at r.t. The mixture was directly characterized by NMR while ECD spectra were recorded in acetonitrile.

${ }^{1} \mathrm{H}$ NMR $\left(600 \mathrm{MHz}\right.$, acetone- $\left.d_{6}\right): 1.71(\mathrm{br} d, J=7.0 \mathrm{~Hz}, 3 \mathrm{H}, \mathrm{H}-$ 14), $2.03-2.10(\mathrm{~m}, 2 \mathrm{H}, \mathrm{H}-9$ ), 4.96 (ddd, $J=2.5,7.8,10.7 \mathrm{~Hz}, 1 \mathrm{H}$, $\mathrm{H}-11$ ), 4.99 (br d, $J=12.7 \mathrm{~Hz}, 1 \mathrm{H}, \mathrm{H}-1 \mathrm{~A}$ ), 5.07 (dd, $J=3,12 \mathrm{~Hz}$, $1 \mathrm{H}, \mathrm{H}-1 \mathrm{~B}$ ), 5.08 (br t, $J=10 \mathrm{~Hz}, 1 \mathrm{H}, \mathrm{H}-10), 5.45$ (br d, $J=9.8 \mathrm{~Hz}$ $1 \mathrm{H}, \mathrm{H}-8$ ), 5.63 (ddq, 15.2, 7.8, 1.6 Hz, 1H, H-12), 5.83 (dq, 15.2, $7.0 \mathrm{~Hz}, 1 \mathrm{H}, \mathrm{H}-13), 6.75(\mathrm{~d}, J=7.9,1 \mathrm{H}, \mathrm{H}-4), 6.77(\mathrm{~d}, J=7.9,1 \mathrm{H}$, $\mathrm{H}-6), 7.12(\mathrm{t}, J=7.9,1 \mathrm{H}, \mathrm{H}-5), 7.34\left(\mathrm{t}, J=7.6,1 \mathrm{H}, \mathrm{H}-4^{\prime}\right), 7.41$ (t, $\left.J=7.6,2 \mathrm{H}, \mathrm{H}-3^{\prime}, \mathrm{H}-5^{\prime}\right), 7.83\left(\mathrm{~d}, J=7.6,2 \mathrm{H}, \mathrm{H}-2^{\prime}, \mathrm{H}-6^{\prime}\right)$. Additional peaks were detected in the region 7.3-7.9 ppm due to residual phenylboronic acid. No residual peaks of unreacted 1 were detected.

\section{COMPUTATIONAL SECTION}

Molecular mechanics and preliminary DFT calculations were run with Spartan16 (Wavefunction, Inc., Irvine CA, 2017), with standard parameters and convergence criteria. DFT and TDDFT calculations were run with Gaussian' $16^{34}$ with default grids and convergence criteria. Conformational searches were run with the Monte Carlo algorithm implemented in Spartan16 using Merck molecular force field (MMFF). The conformers thus obtained were optimized with DFT first at $\omega B$ 97X-D/6-31G(d) level and then at the $\omega \mathrm{B} 97 \mathrm{X}-\mathrm{D} / 6-311 \mathrm{G}+(\mathrm{d}, \mathrm{p})$ level. TDDFT calculations were run with CAM-B3LYP functional and def2-SVP or def2TZVP basis set in vacuo. A second functional (B3LYP) was also tested. Average ECD spectra were computed by weighting component ECD spectra with Boltzmann factors at $300 \mathrm{~K}$ estimated from DFT internal energies. All conformers with population $>1 \%$ at $300 \mathrm{~K}$ were considered. ECD spectra were generated using the program SpecDis, ${ }^{35}$ using dipole-length rotational strengths; the difference with dipole-velocity values was negligible in all cases. Spin-spin coupling constants were estimated by means of Karplus-type equations: the Haasnoot-de Leeuw-Altona ${ }^{36}$ equation including the necessary chemical groups for ${ }^{3} J_{\mathrm{H} 10-\mathrm{H} 11}$ and the ${ }^{3} \mathrm{~J}$-vinyl coupling equation of Garbish $^{37}$ for ${ }^{3} J_{\mathrm{H} 11-\mathrm{H} 12}$ (the equations are provided in the Supporting Information). The parameters for Garbish equations were determined by running NMR-GIAO calculations on E-1methylpent-2-en-1-ol (as molecular model of the C10-C14 chain in 1 and 2) run at B3LYP/pcJ-2 level, ${ }^{38}$ to evaluate the ${ }^{3} J$-vinyl spin-spin coupling as a function of the $\mathrm{H}-\mathrm{C}-\mathrm{C}-\mathrm{H}$ dihedral angle. The simulation included all conformers with population $>0.1 \%$ at $300 \mathrm{~K}$. For each conformer, the ${ }^{3} \mathrm{~J}$ 's were estimated with the abovementioned equations, weighted with the respective Boltzmann factor at $300 \mathrm{~K}$ (from DFT internal energies) and then averaged.

\section{COLEOPTILE AND RADICLE ELONGATION BIOASSAY}

Seeds of buffelgrass (Cenchrus ciliaris) were used for this assay. Compound $1-5$ were first dissolved in DMSO, and then brought to a concentration of $5 \times 10^{-3} \mathrm{M}$ with distilled water (final DMSO concentration $2 \%$ ). For each compound, $250 \mu \mathrm{L}$ of the solution was pipetted into each of three 3.5-cm Petri dishes onto the surface of one filter paper. For the control treatment the seeds were incubated in $2 \%$ DMSO. Six buffelgrass seeds were arranged onto the surface of each filter paper in a pattern that made it possible to track individual seeds. Petri dishes were sealed with parafilm to retard moisture loss and incubated at $25{ }^{\circ} \mathrm{C}$ with a $12: 12$ hour photoperiod. Germination, defined as radicle emergence to $>1 \mathrm{~mm}$, was scored each day for 10 days, and germination day was tracked individually for each seed.
Three days after germination, the coleoptile and radicle length for each seedling were recorded using electronic calipers. Seeds that produced a coleoptile but no radicle were scored as germinated but with a measured coleoptile length and a radicle length of zero, whereas seeds that produced neither a radicle nor a coleoptile were scored as ungerminated. Differential effects of the compounds on germination time and coleoptile and radicle length were evaluated using Ismeans separations from analysis of variance (SAS Proc GLM) on log-transformed data. Germination percentage was not replicated and was therefore not subjected to statistical analysis.

\section{Results and discussion}

$P$. grisea was produced in liquid culture and the organic extract obtained from the culture filtrate was purified as reported in detail in the Experimental section; five metabolites were isolated. Three of these compounds were identified, by comparing their spectroscopic (IR, UV and ${ }^{1} \mathrm{H}$ NMR spectra) data with those previously reported in literature, as (10S,11S)-(-)-epipyriculol, trans-3,4-dihydro-3,4,8-trihydroxy-1(2H)-napthalenone and (4S)isosclerone $\left(\mathbf{3}, \mathbf{4}\right.$ and $\mathbf{5}$, respectively, Fig. 1). ${ }^{25-32}$ Their identification was confirmed by the ESIMS spectra and physical (optical rotation) data. In fact, the ESIMS spectrum of $\mathbf{3}$ showed the potassium $[\mathrm{M}+\mathrm{K}]^{+}$and sodium $[\mathrm{M}+\mathrm{Na}]^{+}$adduct ions at $\mathrm{m} / \mathrm{z}$ 287 and 271 . The optical rotation $\left([\alpha]_{D}^{25}=-31.2\left(c=0.7 \quad \mathrm{CHCl}_{3}\right)\right.$ was very similar to that reported in literature for the natural and synthetic (10S)-isomer of pyriculol, ${ }^{25,27}$ named epipyriculol. The ESIMS spectrum of $\mathbf{4}$ showed the sodium $[\mathrm{M}+\mathrm{Na}]^{+}$adduct ion and the protonated form $\left[\mathrm{M}+\mathrm{H}^{+}\right.$at $\mathrm{m} / \mathrm{z} 217$ and 195, respectively. The ESIMS spectrum of $\mathbf{5}$ showed the potassium $[\mathrm{M}+\mathrm{K}]^{+}$and sodium $[\mathrm{M}+\mathrm{Na}]^{+}$clusters as well as the protonated form $[\mathrm{M}+\mathrm{H}]^{+}$at $\mathrm{m} / \mathrm{z} 217,201$ and 179 , respectively, while its optical rotation $\left([\alpha]_{D}{ }^{25}=+16.8^{\circ}\left(\mathrm{c}=0.1 \mathrm{CHCl}_{3}\right)\right.$ was very similar to that reported in literature for (4S)-isosclerone. ${ }^{32}$ Two additional metabolites were isolated and named pyriculins $A$ and $B$ ( 1 and 2, Figure 1). The first inspection of the ${ }^{1} \mathrm{H}$ and ${ }^{13} \mathrm{C}$ NMR spectra of 1 and 2 carried out in $\mathrm{CD}_{3} \mathrm{OD}$ showed that they were closely related to each other and also to 3 .

1 had a molecular formula $\mathrm{C}_{14} \mathrm{H}_{18} \mathrm{O}_{4}$ as deduced from its HRESI MS spectrum and consistent with six hydrogen deficiencies. Its IR spectrum showed bands typical of hydroxy, olefinic and aromatic groups, ${ }^{39}$ while its UV spectrum exhibited absorption maxima typical of compounds containing an aromatic ring. ${ }^{40}$

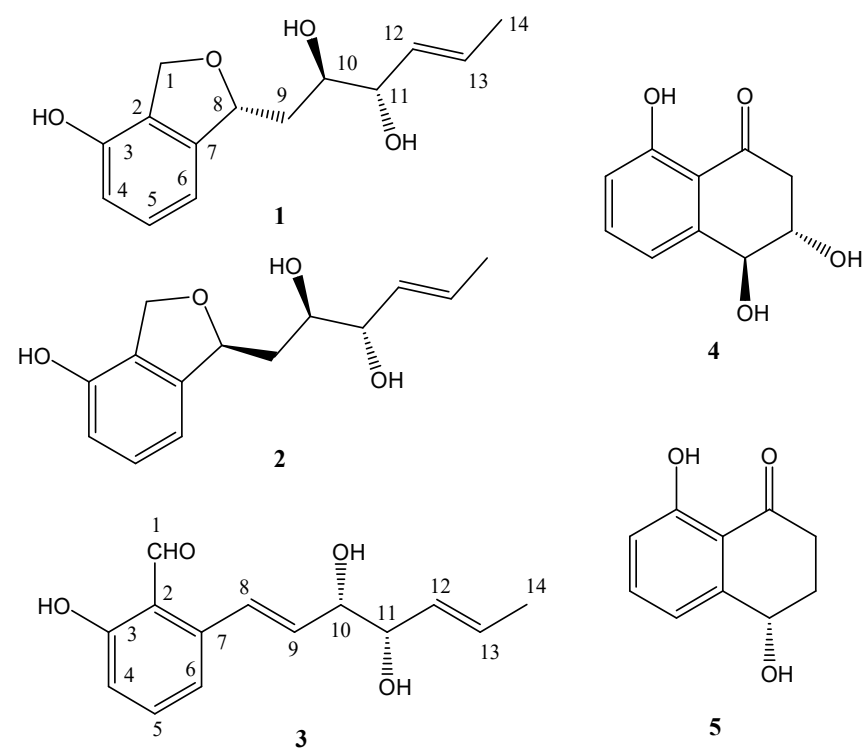

FIGURE 1 Structures of pyriculins A and B (1 and 2), (10S,11S)-(-)epipyriculol (3), trans-3,4-dihydro-3,4,8-trihydroxy-1(2H)napthalenone (4) and (4S)-(+)-isosclerone (5). 
The ${ }^{1} \mathrm{H}$ NMR spectrum of pyriculins $A$ and $B(\mathbf{1}$ and $\mathbf{2})$ was also recorded in acetone- $d_{6}$ (Table 1 ) to increase the signal resolution and to measure the ${ }^{3} J_{\mathrm{H}, \mathrm{H}}$ coupling constants more accurately. The ${ }^{1} \mathrm{H}$ NMR spectrum of pyriculin A (1) showed the signal system of a disubstituted dihydrobenzofuran and those of a monosubstituted hex-4-enediol. In particular, the triplet $(J=7.7$ $\mathrm{Hz}$ ) of $\mathrm{H}-5$ resonated at $\delta 7.11$ and was coupled in the COSY spectrum ${ }^{33}$ with the two adjacent protons $(\mathrm{H}-4$ and $\mathrm{H}-6)$ which appeared as two overlapped doublets $(J=7.7 \mathrm{~Hz})$ at $\delta 6.67$. The same spectrum showed the signals of an oxygenated methylene group $\left(\mathrm{H}_{2} \mathrm{C}-1\right)$ which resonated as a double doublet $(J=12.2$ and $2.1 \mathrm{~Hz})$ and doublet $(J=12.2 \mathrm{~Hz})$ at $\delta 5.03$ and 4.93, respectively. In addition, a broad doublet $(J=8.9 \mathrm{~Hz})$, due to the proton of oxygenated secondary carbon $(\mathrm{CH}-8)$, was observed at $\delta 5.40$. A series of double resonance spectra allowed us to measure its coupling constants as well as those of the other signals as reported in Table 1 . Thus $\mathrm{H}-8$, appearing as a doublet of double doublets $(J=9.7,2.5$ and $2.1 \mathrm{~Hz})$, was coupled in the COSY spectrum ${ }^{33}$ with the signals of the adjacent methylene group $\left(\mathrm{H}_{2} \mathrm{C}-9\right)$ which resonated as two doublets of double doublets $(J=14.5,9.8$ and $2.5 \mathrm{~Hz}$ and $J=14.5,9.7$ and $2.2 \mathrm{~Hz}$ ) at $\delta 1.84$ and 1.76. These latter signals in turn coupled with the proton $(\mathrm{H}-10)$ of a secondary hydroxylated carbon resonating as a doublet of double doublets $(J=9.8,3.8$ and $2.2 \mathrm{~Hz})$ at $\delta 3.83$, being also coupled with the proton $(\mathrm{H}-11)$ of the other adjacent secondary hydroxylated carbon (C-11) appearing as double doublet $(J=6.4$ and $3.8 \mathrm{~Hz})$ at $\delta 3.97$. In the COSY spectrum, ${ }^{33}$ $\mathrm{H}-11$ coupled with the olefinic proton $\mathrm{H}-12$ resonating at $\delta 5.57$ as broad double doublet $(\mathrm{J}=15.4$ and $6.4 \mathrm{~Hz})$. H-12 was transcoupled $(J=15.4 \mathrm{~Hz})$ with the other olefinic proton $\mathrm{H}-13$ resonating as double quartet $(J=15.4$ and $6.3 \mathrm{~Hz})$ at $\delta 5.68$. $\mathrm{H}$ 12 also coupled with a typical allylic constant $(J<1 \mathrm{~Hz})$ with the methyl at $\mathrm{C}-14$, which resonated as broad doublet $(J=6.3)$ at $\delta$ 1.66. The data of ${ }^{13} \mathrm{C}$ NMR spectrum (Table 2) and the couplings observed in the HSQC spectrum ${ }^{33}$ allowed us to assign the signals at $\delta 131.4,129.9,129.0,114.6,112.8,82.4,77.2,72.3$, $71.1,40.2$ and 17.9 to the protonated carbons $\mathrm{C}-13, \mathrm{C}-5, \mathrm{C}-12$, C-4, C-6, C-8, C-11, C-10, C-1, C-9 and C-11, respectively. The quaternary aromatic carbons were also assigned on the basis of the couplings observed in the HMBC spectrum. ${ }^{33}$ In particular, the couplings between $\mathrm{C}-2$ with $\mathrm{H}_{2}-1$ and $\mathrm{H}-4, \mathrm{C}-3$ and $\mathrm{C}-7$ both with $\mathrm{H}_{2}-1, \mathrm{H}-4$ and $\mathrm{H}-5$ allowed us to assign the signal at $\delta 152.6$, 145.5 and 125.9 to C-3, C-7 and C-2.41 Thus, the chemical shifts were assigned to all the protons and corresponding carbons of 1 as reported in Table 2. Furthermore, the couplings observed in the HMBC spectrum between $\mathrm{C}-8$ with $\mathrm{H}_{2}-9, \mathrm{H}-10, \mathrm{H}-6$ and $\mathrm{H}-5$ allowed us to identify $\mathrm{C}-8$ as the connection carbon between the dihydroisobenzofuranyl and the hexanediolyl moieties.

Thus, 1 was formulated as (4E)-1-(4-hydroxy-1,3dihydroisobenzofuran-1-yl)hex-4-ene-2,3-diol.

The structure assigned to 1 was further supported by the other couplings observed in the HMBC (Table 2) and from the data of its HRESI MS spectrum. This latter showed the dimeric sodiated $[2 \mathrm{M}+\mathrm{Na}]^{+}$and the sodiated form $[\mathrm{M}+\mathrm{Na}]^{+}$at $\mathrm{m} / \mathrm{z}$ 523.2309 and 273.1106, respectively.

Pyriculin $\mathrm{B}(2)$ had the same molecular formula $\mathrm{C}_{14} \mathrm{H}_{18} \mathrm{O}_{4}$ of 1 as deduced from its HRESI MS and consistent with six hydrogen deficiencies. As reported above its ${ }^{1} \mathrm{H}$ and ${ }^{13} \mathrm{C}$ NMR spectra (Table 1 and 2) were close to those of 1 and consistent with the bands typical of hydroxy group and aromatic rings observed in its IR spectrum ${ }^{39}$ as well as the absorption maxima exhibited in the UV spectrum..$^{40}$ In particular, the inspection of its ${ }^{1} \mathrm{H}$ and ${ }^{13} \mathrm{C}$ NMR spectra showed the same signals of 1 except for the downfield shift $(\Delta \delta=0.09)$ of $\mathrm{H}-9_{\mathrm{A}}$ as well as the different multiplicity of $\mathrm{H}-8$, which appeared to be a double doublet $(\mathrm{J}=$ 8.4 and $4.6 \mathrm{~Hz}$ ) at $\delta 5.38$ instead that the doublet of double doublets observed in 1 , as the coupling with $\mathrm{H}-1_{\mathrm{A}}$ was not observed. These data suggested that $\mathbf{1}$ and $\mathbf{2}$ are stereoisomeric at C-8. The investigation of its COSY, HSQC and HMBC spectra allowed to assign the chemical shifts to all the protons and the corresponding carbons, which are reported in Table 2, and to formulate 2 as (4E)-1-(4-hydroxy-1,3dihydroisobenzofuran-1-yl)hex-4-ene-2,3-diol.

This structure was supported by all the couplings observed in the HMBC spectrum (Table 2) and from the data of its HRESI MS spectrum which showed the dimeric sodiated $[2 \mathrm{M}+\mathrm{Na}]^{+}$and the sodiated form $[\mathrm{M}+\mathrm{Na}]^{+}$at $\mathrm{m} / \mathrm{z} 523.2309$ and 273.1106, respectively.

The structures of $\mathbf{1}$ and $\mathbf{2}$ are similar to those reported in literature for two compounds isolated in 1973 from the fungus Pyricularia oryzae, ${ }^{42}$ which promoted root elongation of rice seedlings at a concentration of $250 \mathrm{ppm}$. However, only partial NMR data (Table 1) were reported and most $J$-coupling values were missing or approximate. More importantly, the stereochemistry of both compounds was not established except for the relative configuration of the diol moiety, which was assigned as erythro. ${ }^{42}$ Therefore, we decided to undertake a full stereochemical assignment of compounds 1 and 2 . Because of the molecular flexibility, it appeared clear that our collection of NMR data had to be interpreted by means of accurate molecular models. ${ }^{43-45}$ By using a consolidated computational procedure, ${ }^{46}$ we ran a thorough conformational analysis with molecular mechanics (Merck molecular force field), followed by geometry optimizations with density functional theory (DFT) using the $\omega B 97 X-D$ functional ${ }^{47}$ first with $6-31 \mathrm{G}(\mathrm{d})$ and then with 6$311+G(d, p)$ basis set. The computations were run on the four possible diastereomers of compounds 1 and 2 , namely the erythro couple $(8 R, 10 R, 11 S)$ and $(8 S, 10 R, 11 S)$, and the threo couple $(8 R, 10 R, 11 R)$ and $(8 S, 10 R, 11 R)$. We obtained for each isomer a large set of low-energy structures with about 15 conformations having a population $>1 \%$ at $300 \mathrm{~K}$ in each case. To assign the relative configuration of the three centers of chirality, we looked at the ${ }^{3} \mathrm{~J}_{\mathrm{H}-\mathrm{H}}$ spin-spin couplings involving $\mathrm{H}$ $10, \mathrm{H}-11$ and $\mathrm{H}-12$. We focused on the set of calculated dihedral angles between $\mathrm{H}-10 / \mathrm{H}-11$ and $\mathrm{H}-11 / \mathrm{H}-12$, and applied the appropriate Karplus-type equations, meaning the Haasnoot-de Leeuw-Altona equation including the necessary chemical groups ${ }^{48}$ for the ${ }^{3} J_{\mathrm{H} 10-\mathrm{H} 11}$ coupling, and the ${ }^{3} \mathrm{~J}$-vinyl coupling equation of Garbish ${ }^{44}$ for the ${ }^{3} J_{\mathrm{H} 11-\mathrm{H} 12}$ coupling (the equations are provided in the Supporting Information).

TABLE $2{ }^{13} \mathrm{C}$ NMR data and $\mathrm{HMBC}$ of $\mathbf{1}$ and $\mathbf{2}$, recorded in MeOD at $500 \mathrm{MHz}^{\mathrm{a}, \mathrm{b}}$

\begin{tabular}{|c|c|c|c|c|}
\hline & 1 & & 2 & \\
\hline position & $\delta_{c}^{c}$ & HMBC & $\delta_{c}^{c}$ & HMBC \\
\hline 1 & $71.1 \mathrm{t}$ & $\mathrm{H}-4, \mathrm{H}-6$ & $71.5 \mathrm{t}$ & $\mathrm{H}-4$ \\
\hline 2 & $125.9 \mathrm{~s}$ & $\begin{array}{l}\mathrm{H}_{2}-1, \mathrm{H}-4, \\
\mathrm{H}-5, \mathrm{H}-6\end{array}$ & $125.9 \mathrm{~s}$ & $\begin{array}{l}\mathrm{H}_{2}-1, \mathrm{H}-4, \mathrm{H}- \\
5, \mathrm{H}-6\end{array}$ \\
\hline 3 & $152.6 \mathrm{~s}$ & $\begin{array}{l}\mathrm{H}_{2}-1, \mathrm{H}-4, \\
\mathrm{H}-5\end{array}$ & $152.6 \mathrm{~s}$ & $\mathrm{H}_{2}-1, \mathrm{H}-4, \mathrm{H}-5$ \\
\hline 4 & $114.6 \mathrm{~d}$ & $\begin{array}{l}\mathrm{H}_{2}-1, \mathrm{H}-5, \\
\mathrm{H}-6\end{array}$ & $114.9 \mathrm{~d}$ & $\mathrm{H}_{2}-1, \mathrm{H}-5, \mathrm{H}-6$ \\
\hline 5 & $129.9 \mathrm{~d}$ & $\mathrm{H}-4, \mathrm{H}-6$ & $130.1 \mathrm{~d}$ & \\
\hline 6 & $112.8 \mathrm{~d}$ & $\begin{array}{l}\mathrm{H}_{2}-1, \mathrm{H}-4, \\
\mathrm{H}-5\end{array}$ & $113.3 d$ & $\mathrm{H}_{2}-1, \mathrm{H}-4, \mathrm{H}-5$ \\
\hline 7 & $145.5 \mathrm{~s}$ & & $145.2 \mathrm{~s}$ & $\begin{array}{l}\mathrm{H}_{2}-1, \mathrm{H}-5, \mathrm{H}- \\
6, \mathrm{H}_{2}-9\end{array}$ \\
\hline 8 & $82.4 \mathrm{~d}$ & $\begin{array}{l}\mathrm{H}_{2}-1, \mathrm{H}-5, \\
\mathrm{H}-6, \mathrm{H}_{2}-9, \\
\mathrm{H}-10\end{array}$ & $84.2 d$ & $\begin{array}{l}\mathrm{H}_{2}-1, \mathrm{H}-5, \mathrm{H}- \\
6, \mathrm{H}_{2}-9, \mathrm{H}-10\end{array}$ \\
\hline 9 & $40.2 \mathrm{t}$ & $\mathrm{H}-11$ & $40.1 \mathrm{t}$ & $\mathrm{H}-10, \mathrm{H}-11$ \\
\hline 10 & $72.3 d$ & $\mathrm{H}_{2}-9, \mathrm{H}-11$ & $73.6 \mathrm{~d}$ & $\mathrm{H}_{2}-9, \mathrm{H}-11$ \\
\hline 11 & $77.2 \mathrm{~d}$ & $\begin{array}{l}\mathrm{H}_{2}-9, \mathrm{H}- \\
10, \mathrm{H}-12, \\
\mathrm{H}-13\end{array}$ & $76.8 \mathrm{~d}$ & $\begin{array}{l}\mathrm{H}_{2}-9, \mathrm{H}-10, \mathrm{H}- \\
12, \mathrm{H}-13\end{array}$ \\
\hline 12 & $129.0 \mathrm{~d}$ & $\begin{array}{l}\mathrm{H}-11, \mathrm{Me}- \\
14\end{array}$ & $129.3 d$ & $\mathrm{H}-11, \mathrm{Me}-14$ \\
\hline 13 & $131.4 \mathrm{~d}$ & $\begin{array}{l}\mathrm{H}-10, \mathrm{H}- \\
11, \mathrm{Me}-14\end{array}$ & $131.5 \mathrm{~d}$ & $\begin{array}{l}\mathrm{H}-10, \mathrm{H}-11, \\
\mathrm{Me}-14\end{array}$ \\
\hline 14 & $17.9 q$ & $\mathrm{H}-12, \mathrm{H}-13$ & $17.8 \mathrm{q}$ & $\mathrm{H}-12, \mathrm{H}-13$ \\
\hline
\end{tabular}

${ }^{a}$ The chemical shifts are in $\delta$ values (ppm) from TMS. ${ }^{b} 2 \mathrm{D}{ }^{1} \mathrm{H},{ }^{1} \mathrm{H}$ (COSY), and $2 \mathrm{D}{ }^{13} \mathrm{C},{ }^{1} \mathrm{H}$ (HSQC) NMR experiments delineated the correlations of all the protons and the corresponding carbons. 'Multiplicities were assigned by DEPT spectrum. 
TABLE 3 Experimental and estimated ${ }^{3} \mathrm{~J}_{\mathrm{H}-\mathrm{H}}$ spin-spin couplings.

\begin{tabular}{llll}
\hline compound & Source & ${ }^{3} J_{\mathrm{H} 10-\mathrm{H} 11}$ & ${ }^{3} J_{\mathrm{H} 11-\mathrm{H} 12}$ \\
$\mathbf{1}$ & Exp & 3.8 & 6.4 \\
$\mathbf{2}$ & Exp & 3.7 & 6.1 \\
erythro $(8 R, 10 R, 11 S)$ & Calc & 3.5 & 7.1 \\
erythro $(8 S, 10 R, 11 S)$ & Calc & 4.4 & 8.5 \\
threo $(8 R, 10 R, 11 R)$ & Calc & 7.3 & 8.1 \\
threo $(8 S, 10 R, 11 R)$ & Calc & 6.1 & 8.3
\end{tabular}

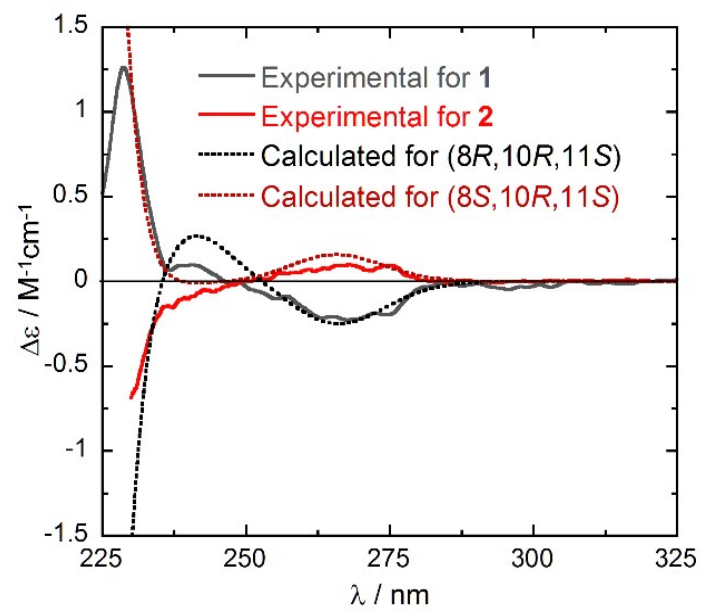

FIGURE 2. Experimental ECD spectra of pyriculins $A$ and $B(1-2)$ in acetonitrile and calculated ECD spectra for two possible isomers of 1 and 2 at CAM-B3LYP/def2-TZVP level as Boltzmann average over 8 DFT structures (optimized at $\omega B 97 X-D / 6-311+G(d, p)$ level). Calculated spectra plotted as sums of Gaussians with $\sigma=0.25$ exponential half-width; wavelength correction $+30 \mathrm{~nm}$; scaled by a factor 5 .

The estimation was run for the four possible isomers including all DFT conformers with population $>0.1 \%$ at $300 \mathrm{~K}$. The estimated and experimental $J$-couplings are listed in Table 3. While the values of ${ }^{3} J_{\mathrm{H} 11-\mathrm{H} 12}$ were not helpful, those of ${ }^{3} J_{\mathrm{H} 10-\mathrm{H} 11}$ suggested the relative configuration of the diol moiety to be erythro. We hoped that a whole set of $\mathrm{C}-\mathrm{H}$ coupling constants would allow us to better confirm the assignment. ${ }^{49}$ Therefore, we ran $\mathrm{J}$-modulated HMBC experiments on compound 1 to measure the desired ${ }^{2,3} J_{C-H}$ values; however, the only clearly measurable coupling was ${ }^{2} J_{\mathrm{C} 10-\mathrm{H} 11} \approx 8 \mathrm{~Hz}$, while the second relevant ${ }^{2} \mathrm{~J}_{\mathrm{C} 11-\mathrm{H} 10}$ was too small. The combination of one very large and one small ${ }^{2} J_{\mathrm{C}-\mathrm{H}}$ coupling for a 1,2-diol system is in accord with the erythro configuration, provided that gauche conformers are largely populated. ${ }^{49}$ This is indeed the case for our set of calculated structures of erythro type, especially the $(8 R, 10 R, 11 S)$ one (anti conformers amounted to only $11 \%$ of the conformational ensemble).

Electronic circular dichroism (ECD) spectra were measured on compounds 1 and $\mathbf{2}$ in acetonitrile solution (Fig. 2). The spectra were both very weak and only one band could be measured with sufficient accuracy. The ECD band between 250 and $285 \mathrm{~nm}$ (negative for 1 and positive for 2 ) is allied with the ${ }^{1} L_{b}$ transition of the aromatic chromophore; the associated $g$-factor $(\Delta \varepsilon / \varepsilon)$ was $\approx 10^{-4}$, well above the instrumental sensitivity. The opposite sign of the ${ }^{1} L_{b}$ band for compounds 1 and 2 offered the definite proof that the two compounds had indeed opposite configuration at C8. In fact, this band is very diagnostic of the configuration of aromatic compounds, and it is primarily sensitive to the chirality of the fused heterocyclic ring. ${ }^{50}$ This was further demonstrated by running ECD calculations by time-dependent DFT (TDDFT) on DFT-optimized structures ${ }^{46}$ with $(8 R, 10 R, 11 S)$ and $(8 S, 10 R, 11 S)$ configuration. The calculated spectra (CAMB3LYP/def2-TZVP level of calculation, averaged over 8 conformers with population $>1.5 \%$ ) were the mirror image of each other in the ${ }^{1} \mathrm{~L}_{\mathrm{b}}$-band region; the $(8 R, 10 R, 11 S)$ isomer led to negative ${ }^{1} L_{b}$ band, and the $(8 S, 10 R, 11 S)$ isomer to positive one. Thus, the comparison between experimental and calculated spectra allowed us to assign the configuration at C-8 as $(8 R)$ for 1 and $(8 S)$ for 2.

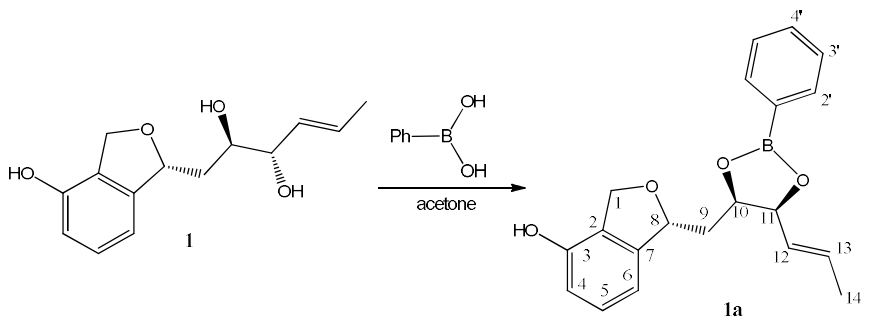

FIGURE 3. Conversion of pyriculin A (1) in its phenyl dioxaborolane (1a).

The assignment was essentially based on a single weak ECD band, and an independent confirmation was desirable. We tried to measure vibrational $C D$ spectra (VCD), which were however too weak because of the limited amount available of the two compounds.

The combination of NMR and ECD results on compounds 1 and 2 led to the following conclusions: (a) compound $\mathbf{1}$ is $(8 R)$ and compound 2 is (8S); (b) both compounds have relative erythro configuration of the 1,2-diol moiety; (c) the absolute configuration of the diol moiety is also the same (otherwise they would be enantiomers). Unfortunately, ECD spectra were not useful for assignment of absolute configurations at C-10 and C11. To establish this last piece of information, we resorted to derivatization of compound 1 with phenylboronic acid to transform it into the corresponding cyclic boronate diester or dioxaborolane (1a, Fig. 3). In this way, we aimed at reducing the conformational freedom and inserting a second phenyl chromophore capable of giving exciton-coupled ECD spectra by interacting with the preexisting chromophore. ${ }^{51,52}$

The dioxaborolane 1a was characterized by NMR $\left({ }^{1} \mathrm{H}\right.$ NMR, COSY and ROESY) and ECD spectra. At the same time, two possible isomers of $1 \mathrm{a}$ with $(8 R, 10 R, 11 S)$ and $(8 R, 10 S, 11 R)$ configuration were modeled by molecular mechanics conformational searches, DFT geometry optimizations ( $\omega B$ B97X$\mathrm{D} / 6-311+\mathrm{G}(\mathrm{d}, \mathrm{p})$ level), and TDDFT calculations (CAMB3LYP/def2-SVP level). In the NMR spectra of 1a, protons $\mathrm{H}-10$ and $\mathrm{H}-11$ were downfield shifted with respect to 1 and appeared as a broad triplet at $\delta 5.06$ and a well resolved doublet of double doublets at $\delta 4.96(J=10.7,8.0$ and $2.5 \mathrm{~Hz})$, respectively.

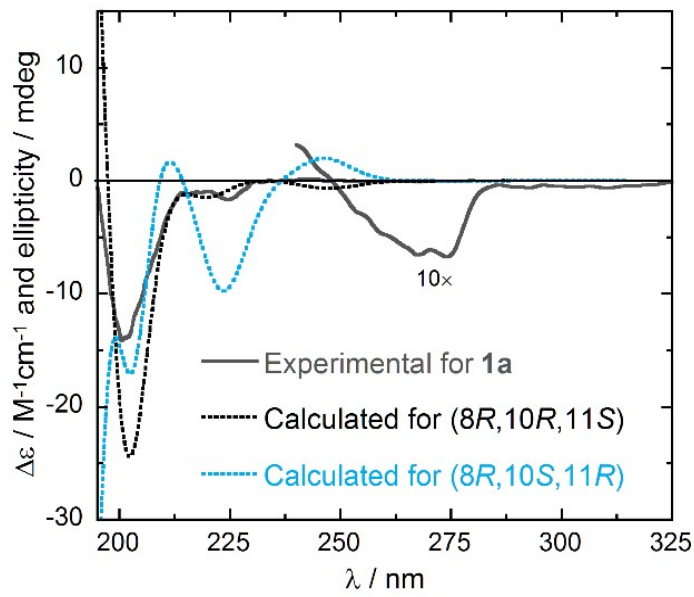

FIGURE 4 Experimental ECD spectrum of the phenyl dioxaborolane of pyriculin $A$ (1a) in acetonitrile (with two different cells) and calculated ECD spectra for two possible isomers of 1a at CAMB3LYP/def2-SVP level as Boltzmann average over 10 DFT structures (optimized at $\omega B 97 X-D / 6-311+G(d, p)$ level). Calculated spectra plotted as sums of Gaussians with $\sigma=0.2$ exponential halfwidth; wavelength correction $+15 \mathrm{~nm}$. 

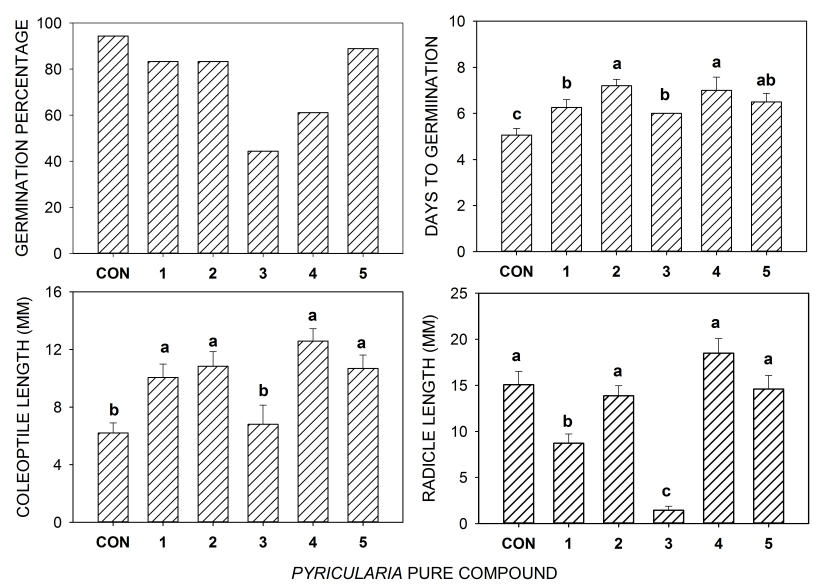

FIGURE 5 Effect of five pure compounds isolated from $P$. grisea on germination percentage, germination time, 3-day coleoptile length, and 3-day radicle length in a buffelgrass seed bioassay. Error bars represent standard error of the mean. For each response variable, columns headed by the same letter are not significantly different at $P$ $<0.05$ based on mean separation from analysis of variance on logtransformed data. CON is the control.

The very large value for the spin-spin coupling ${ }^{3} J_{\mathrm{H} 10-\mathrm{H} 11}=$ $10.7 \mathrm{~Hz}$, and the strong NOE cross-peak seen in the ROESY spectrum for $\mathrm{H}-10$ and $\mathrm{H}-11$, demonstrated that these two hydrogens are cis-oriented in the dioxaborolane ring; similarly, ROESY cross-peaks were detected between $\mathrm{H}-9$ and both $\mathrm{H}-12$ and $\mathrm{H}-13$.

The relative erythro configuration of the diol moiety was thus definitely proved. ROESY cross-peaks were also detected between $\mathrm{H}-8$ and both $\mathrm{H}-10$ and $\mathrm{H}-11$. When checked against the calculated conformational ensembles, the related short contacts were only evident for the $(8 R, 10 R, 11 S)$ isomer, but not for the $(8 R, 10 S, 11 R)$ isomer (see structures in the Supporting Information).

Finally, the experimental ECD spectrum of $1 a$ in acetonitrile was well reproduced by TDDFT calculations on the $(8 R, 10 R, 11 S)$ isomer, while the spectrum calculated on the $(8 R, 10 S, 11 R)$ isomer did not match the experiment (Fig. 4).

In conclusion, we could finally assign the full stereochemistry of pyriculins $\mathrm{A}$ and $\mathrm{B}$ as $(8 R, 10 R, 11 S)-1$ and $(8 S, 10 R, 11 S)-2$, respectively.

(10S,11S)-(-)-Epipyriculol (3) was isolated for the first time as natural product in $1991^{26}$ from Pyricularia oryzae and proved to be phytotoxic when tested by rice leaf puncture bioassay. ${ }^{26}$

Compound 4 is a natural polyhydroxylated $\alpha$-tetralone, ${ }^{29}$ a known metabolite implicated in the branched pathway of fungal DHN-melanin biosynthesis, isolated from different microorganisms. ${ }^{53,54}$ It was first isolated from Pyricularia oryzae in $1972^{28}$ and was able to stunt the growth of rice seedlings at high concentrations, but also to stimulate the growth of seedlings at low concentrations after $24 \mathrm{~h}$. Compound 4 was recently isolated from the orchid-associated fungal strain Daldinia eshscholtzii along with diverse aromatic polyketides and new naphthalene derivatives. ${ }^{55}$

$(4 S)$-Isosclerone (5) is a known phytotoxic naphthalenone pentaketide produced by different fungal and plant species. This is the first time it has been isolated from the culture filtrate of the fungus P.grisea. $\mathbf{5}$ is known to be produced by Poaeacremonium alephilum and Phoemoniella chlamydospora involved in the ESCA grapevine disease. ${ }^{30} \mathbf{5}$ is the enantiomer of regiolone, the main phytotoxin isolated from Botrytis fabae, the causal agent of chocolate spot disease of Vicia faba. The relation between the absolute configuration of the two compounds and their phytotoxic activity has been discussed. ${ }^{32}$

When 1-5 were assayed on buffelgrass in a coleoptile and radicle elongation test, (10S,11S)-(-)-epipyriculol (3) was demonstrated to be the most toxic compound (Fig. 5). Germination was much reduced and also delayed relative to the control, and radicle development was almost completely suppressed. All five compounds delayed seed germination significantly relative to the control, and trans-3,4-dihydro-3,4,8trihydroxy-1(2H)-napthalenone (4) also apparently reduced germination percentage. For coleoptile length, 3 did not differ from the control, while the other four compounds had significantly greater coleoptile development than the control, indicating a growth-stimulating effect. Pyriculin A (1) and 3 were the only compounds to negatively affect the radicle, but 1 had significantly less negative impact than $\mathbf{3}$ on radicle development. The complexity of these results suggests a further investigation to assay the different metabolites in mixture to evaluate their synergism or additive action. Extracts from liquid culture filtrates of different strains of this pathogen vary widely in their toxicity to buffelgrass seedlings, possibly because different strains of the fungus from buffelgrass produce these compounds in different amounts. Effects vary from strong toxicity, as in the strain selected here for chemical characterization, to a definite stimulatory effect on radicle and/or coleoptile growth.

\section{Conclusions}

This manuscript reports on the isolation of two monosubstituted hex-4-ene-2,3-diols, named pyriculins $A$ and $B$ (1 and 2), $(10 S, 11 S)-(-)$-epipyriculol, trans-3,4-dihydro-3,4,8-trihydroxy$1(2 H)$-napthalenone and $(4 S)-(+)$-isosclerone $(3,4$ and $\mathbf{5})$ from the culture filtrates of the fungus $P$. grisea. The full relative and absolute stereochemistry of $\mathbf{1}$ and $\mathbf{2}$ was established for the first time by a combination of spectroscopic and computational techniques. Comparing the structures of $\mathbf{1 , 2}$ and $\mathbf{3}$ and their biological activities, the presence of the aldehyde group at $\mathrm{C}-2$ and the unstauration at C-8 of $\mathbf{3}$ seems to play an important role in imparting phytotoxicity.

\section{Acknowledgments}

M.G. thanks the support from the Polish Ministry of Science and Higher Education ('Mobilnosc Plus' grant no. 1286/MOB/IV/2015/0) and Wroclaw Centre for Networking and Supercomputing (WCSS). This work was funded in part by support from the US Forest Service, State and Private Forestry, Biological Control of Invasive Plants grant program. We thank Richard Reardon and Allen White for their continued support of this project, and Dana Backer and Kimberly Wahl-Villarreal for making field pathogen collections.

\section{Supplementary Material}

Supplementary data associated with this article can be found in the online version, at http://dx.doi.org.

\section{REFERENCES AND NOTES}

1. Tinoco-Ojanguren $C$, Reyes-Ortega I, Sánchez-Coronado ME, Molina-Freaner F, Orozco-Segovia A. Germination of an invasive Cenchrus ciliaris L.(buffel grass) population of the Sonoran Desert under various environmental conditions. $S$ Afr J Bot. 2016; 104:112-117.

2. Bogdan AV. Tropical Pasture and Fodder Plants (Grasses and Legumes). London:Longman; 1977; pp 66-74.

3. 't Mannetje L, Kersten SMM. In: 't Mannetje L, Jones RM, Eds. Plant Resources of South-East Asia No. 4. Forages; Wageningen:Pudoc Scientific Publishers; 1992; pp. 77-79.

4. Franklin KA, Molina-Freaner F. Consequences of buffelgrass pasture development for primary productivity, perennial plant richness, and vegetation structure in the drylands of Sonora, Mexico. Conserv Biol. 2010; 24:1664-1673.

5. Olsson AD, Betancourt JL, Crimmins MA, Marsh SE. Constancy of local spread rates for buffelgrass (Pennisetum ciliare L.) in the Arizona Upland of the Sonoran Desert. J Arid Environ. 2012; 87:136-143. 
6. Jernigan MB, McClaran MP, Biedenbender SH, Fehmi JS. Uprooted buffelgrass thatch reduces buffelgrass seedling establishment. Arid Land Res Manag. 2016; 30:320-329.

7. Rutman S, Dickson L. In: Tellman B, Ed. Invasive exotic species in the Sonoran region. Tucson:University of Arizona Press; 2002, pp 311-330.

8. Bowers JE, Bean TM, Turner RM. Two decades of change in distribution of exotic plants at the Desert Laboratory, Tucson, Arizona. Madroño 2006; 53:254-265.

9. Stevens J, Falk DA. Can buffelgrass invasions be controlled in the American Southwest? Using invasion ecology theory to understand buffelgrass success and develop comprehensive restoration and management. Ecol Restoration. 2009; 27:417-427.

10. Marshall VM, Lewis MM, Ostendorf B. Buffelgrass (Cenchrus ciliaris) as an invader and threat to biodiversity in arid environments: a review. J Arid Environ. 2012; 78:1-12.

11. Lyons KG, Maldonado-Leal BG, Owen G. Community and ecosystem effects of buffelgrass (Pennisetum ciliare) and nitrogen deposition in the Sonoran Desert. Invasive Plant Sci Manag. 2013; 6:65-78.

12. Burquez-Montijo AM, Miller ME, Yrizar AM, Tellman B. Mexican grasslands, thornscrub, and the transformation of the Sonoran Desert by invasive exotic buffelgrass (Pennisetum ciliare). In: Tellman B, editor. Invasive exotic species in the Sonoran region. Tucson: University of Arizona Press, The Arizona-Sonora Desert Museum; 2002; pp 126146.

13. Bean TM. Final Report: Efficacy of imazapic and glyphosate for pre and post emergence control of buffelgrass and Progress Report: Effectiveness of monocot-specific and pre emergence herbicide for control of buffelgrass. Forest Service Pesticide Impact Assessment Program Awards R30110 and R3-2012-02, 2012.

14. Cimmino A, Masi M, Evidente M, Superchi S, Evidente A. Fungal phytotoxins with potential herbicidal activity: chemical and biological characterization. Nat Prod Rep. 2015; 32:1629-1653.

15. Masi M, Evidente A, Meyer S, Nicholson J, Muñoz, A. Effect of strain and cultural conditions on the production of cytochalasin B by the potential mycoherbicide Pyrenophora semeniperda (Pleosporaceae, Pleosporales). Biocontrol Sci Technol. 2014; 24:53-64.

16. Masi M, Meyer S, Cimmino A, Clement S, Black B, Evidente A. Pyrenophoric acids $B$ and $C$, two new phytotoxic sesquiterpenoids produced by Pyrenophora semeniperda. $J$ Agric Food Chem. 2014; 62:10304-10311.

17. Masi M, Meyer SE, Cimmino A, Andolfi A, Evidente A. Pyrenophoric acid, a phytotoxic sesquiterpenoid penta-2, 4dienoic acid produced by a potential mycoherbicide, Pyrenophora semeniperda. J Nat Prod. 2014; 77:925-930.

18. Masi M, Meyer SE, Clement S, Andolfi A, Cimmino A, Evidente A. Spirostaphylotrichin W, a spirocyclic y-lactam isolated from liquid culture of Pyrenophora semeniperda, a potential mycoherbicide for cheatgrass (Bromus tectorum) biocontrol. Tetrahedron 2014; 70:1497-1501.

19. Meyer S, Masi M, Clement S, Davis TL, Beckstead J. Mycelial growth rate and toxin production in the seed pathogen Pyrenophora semeniperda: resource trade - offs and temporally varying selection. Plant Pathology 2015; 64:1450-1460.

20. Masi M, Meyer S, Clement S, Cimmino A, Cristofaro $M$, Evidente A. Cochliotoxin, a dihydropyranopyran-4, 5-dione, and Its analogues produced by Cochliobolus australiensis display phytotoxic activity against buffelgrass (Cenchrus ciliaris). J Nat Prod. 2017; 80:1241-1247.

21. Rodríguez O, Gonzalez-Dominguez J, Krausz JP, Odvody GN, Wilson JP, Hanna WW, Levy M. First report and epidemics of buffelgrass blight caused by Pyricularia grisea in South Texas. Plant Disease 1999; 83:398-398.

22. Perrott RF, Chakraborty S. Pyricularia grisea causes blight of buffel grass (Cenchrus ciliaris) in Queensland, Australia. Trop Grasslands. 1999; 33:201-206.
23. Diaz-Franco A, Mendez-Rodríguez A, Garza-Cedillo R. Tizón foliar del pasto buffel: Su presencia in Tamaulipas, Mexico. Agricultura Técnica en México 2007; 33:285-295.

24. Tsurushima T, LeDinh D, Kawashima K, Murakama J, Nakayashiki H, Tosa $\mathrm{Y}$, Mayama S. Pyrichalasin $\mathrm{H}$ production and pathogenicity of Digitaria - specific isolates of Pyricularia grisea. Mol Plant Pathol. 2005; 6:605-613.

25. Suzuki M, Sugiyama T, Watanabe $M$, Murayama $T$, Yamashita K. Syntheses of all four stereoisomers of pyriculol. Agric Biol Chem. 1987; 51:2161-2166.

26. Kono $Y$, Sekido S, Yamaguchi I, Kondo H, Suzuki Y, Neto GC, Sakurai A, Yaegashi, H. Structures of two novel pyriculol-related compounds and identification of naturally produced epipyriculol from Pyricularia oryzae. Agric Biol Chem. 1991; 55:2785-2791.

27. Leyva A, Blum FE, Ley SV. A new synthesis of (-) epipyriculol: a phytotoxic metabolite. Tetrahedron 2008; 64:4711-4717.

28. Iwasaki S, Muro H, Nozoe S, Okuda S, Sato Z. Isolation of 3 , 4-dihydro-3, 4, 8-trihydroxy-1 (2H)-naphthalenone and tenuazonic acid from Pyricularia oryzae cavara. Tetrahedron Letters 1972;13:13-16.

29. Couché E, Fkyerat A, Tabacchi R. Stereoselective synthesis of cis - and trans - 3,4 - dihydro - 3, 4, 8 trihydroxynaphthalen - $1(2 H)$ - one. Helv Chim Acta. 2009; 92:903-917.

30. Evidente A, Sparapano L, Andolfi A, Bruno G. Two naphthalenone pentakides from liquid cultures of Phaeoacremonium aleophilum, a fungus associated with esca of grapevine. Phytopathol. Mediterr. 2000; 39:162-168.

31. Tabacchi R, Fkyerat A, Poliart C, Dubin GM. Phytotoxins from fungi of esca of grapevine. Phytopathol Mediterr, 2000, 39, 156-161.

32. Evidente A, Superchi S, Cimmino A, Mazzeo G, Mugnai L, Rubiales $D$, Andolfi A, Villegas-Fernández AM. Regiolone and isosclerone, two enantiomeric phytotoxic naphthalenone pentaketides: computational assignment of absolute configuration and its relationship with phytotoxic activity. Eur J Org Chem. 2011; 28:5564-5570.

33. Berger, S.; Braun, S. 200 and More Basic NMR Experiments: a Practical Course; Weinheim:Wiley-VCH; 2004.

34. Frisch MJ, Trucks GW, Schlegel HB, Scuseria GE, Robb MA, Cheeseman JR, Scalmani G, Barone V, Petersson GA, Nakatsuji $\mathrm{H}$, Li X, Caricato M, Marenich AV, Bloino J, Janesko BG, Gomperts R, Mennucci B, Hratchian HP, Ortiz JV, Izmaylov AF, Sonnemberg JL, Williams-Young D, Ding F, Lipparini F, Egidi F, Goings J, Peng B, Petrone A, Henderson T, Ranasinghe D, Zakrzewski VG, Gao J, Rega N, Zheng G, Liang W, Hada M, Ehara M, Toyota K, Fukuda $R$, Hasegawa J, Ishida M, Nakajima $T$, Honda $Y$, Kitao $O$, Nakai $\mathrm{H}$, Vreven $\mathrm{T}$, Throssell K, Montgomery JJA, Peralta JE, Ogliaro F, Bearpark M, Heyd JJ, Brothers E, Kudin KN, Staroverov VN, Keith TA, Kobayashi R, Normand J, Raghavachari K, Rendell A, Burant JC, lyengar SS, Tomasi J, Cossi M, Millam JM, Klene M, Adamo C, Cammi R, Ochterski JW, Martin RL, Morokuma K, Farkas O, Foresman JB, Fox DJ. Gaussian 16, Revision A.03, Wallingford:Gaussian Inc; 2016

35. Bruhn T, Schaumloeffel A, Hemberger Y, Bringmann G. SpecDis: Quantifying the comparison of calculated and experimental electronic circular dichroism spectra. Chirality 2013; 25:243-249

36. Altona, C. Vicinal Coupling constants and conformation of biomolecules. eMagRes. 1996.

37. Garbisch EW. Conformations. VI. Vinyl-allylic proton spin couplings. J Am Chem Soc. 1964; 86:5561-5564.

38. Jensen $\mathrm{F}$. The basis set convergence of spin-spin coupling constants calculated by density functional methods. J Chem Theory Comput. 2006; 2:1360-1369.

39. Nakanishi K, Solomon PH. Infrared Absorption Spectroscopy; Oakland:Holden Day; 1977; pp 17-44. 
40. Pretsch E, Bühlmann P, Affolter C. Structure Determination of Organic Compounds - Tables of Spectral Data; Berlin:Springer-Verlag; 2000; pp 161-243.

41. Breitmaier E, Voelter W. Carbon-13 NMR Spectroscopy; Weinheim:VCH; 1987; pp 183-280.

42. Iwasaki S, Muro H, Sasaki K, Nozoe S, Okuda S, Sato Z. solations of phytotoxic substances produced by Pyricularia oryzae Cavara. Tetrahedron Letters 1973; 14:3537-3542.

43. Mazzanti A, Casarini D. Recent trends in conformational analysis. Wiley Interdiscip Rev Comput Mol Sci. 2012; 2: 613-641.

44. Pescitelli G, Di Bari L, Berova N. Conformational aspects in the studies of organic compounds by electronic circular dichroism. Chem Soc Rev. 2011; 40:4603-4625.

45. Pescitelli G, Kurtán T, Flörke U, Krohn K. Absolute structural elucidation of natural products- $A$ focus on quantum mechanical calculations of solid-state CD spectra. Chirality, 2009; 21: E181-E201.

46. Pescitelli G, Bruhn T. Good computational practice in the assignment of absolute configurations by TDDFT calculations of ECD spectra. Chirality 2016; 28:466-474

47. Chai JD, Head-Gordon M. Systematic optimization of longrange corrected hybrid density functionals. J Chem Phys, 2008; 128:084106.

48. Haasnoot CAG, de Leeuw FA, Altona C. The relationship between proton-proton NMR coupling constants and substituent electronegativities-I: an empirical generalization of the Karplus equation. Tetrahedron, 1980, 36:2783-2792.
49. Bifulco G, Dambruoso P, Gomez-Paloma L, Riccio R. Determination of relative configuration in organic compounds by NMR spectroscopy and computational methods. Chem Rev. 2007; 107: 3744-3779.

50. Kurtan T, Antus S, Pescitelli G. In: Berova N, Polavarapu PL, Nakanishi K, Woody RW, editors. Comprehensive chiroptical spectroscopy; Hoboken:Wiley; 2012; Vol 2, pp 73-114.

51. Superchi S, Donnoli MI, Rosini C. Determination of the absolute configuration of 1-arylethane-1, 2-diols by a nonempirical analysis of the CD spectra of their 4biphenylboronates. Org Lett. 1999; 1:2093-2096.

52. Superchi, S, Casarini D, Summa C, Rosini C. A general and nonempirical approach to the determination of the absolute configuration of 1-aryl-1,2-diols J. Org. Chem. 2004; 69:1685-1694.

53. Borgschulte K, Rebuffat S, Trowitzsch-Kienast W, Schomburg D, Pinon J, Bodo B. Isolation and structure elucidation of hymatoxins B-E and other phytotoxins from Hypoxylon mammatum fungal pathogen of leuce poplars. Tetrahedron 1991; 47:8351-8360.

54. Gremaud G, Tabacchi R. Relationship between the fungus Ceratocystis fimbriata coffea and the canker disease of the coffee tree. Phytochemistry 1996; 42:1547-1549.

55. Barnes EC, Jumpathong J, Lumyong S, Voigt K, Hertweck C. Daldionin, an unprecedented binaphthyl derivative, and diverse polyketide congeners from a fungal Orchid endophyte. Chem. Eur.J. 2016; 22:4551 -4555.

\section{Graphical Abstract}<smiles>C/C=C/[C@H](O)[C@H](O)C[C@@H]1OCc2c(O)cccc21</smiles><smiles>C/C=C/[C@H](O)[C@H](O)C[C@@H]1OCc2c(O)cccc21</smiles> 